\title{
DIGITAL RECEIPTS OF ONLINE TRANSACTIONS IN THE RECONCILIATION PROCESS AND THE PREPARATION OF FINANCIAL REPORTS
}

\author{
Ferry Kosadi $^{{ }^{*} \text {, Wajib Ginting }}{ }^{1}$, and Vina Merliana ${ }^{1}$ \\ ${ }^{1}$ Accounting, Sekolah Tinggi Ilmu Ekonomi Indonesia Membangun (Inaba), Bandung, 40266, \\ Indonesia
}

\begin{tabular}{|c|c|}
\hline ABSTRACT & ARTICLE INFO \\
\hline $\begin{array}{l}\text { Introduction/Main Objectives: This research seeks to analyze the use of } \\
\text { digital receipts and multi-platform e-commerces' data integration and the } \\
\text { influence they have on the process of reconciliation and the preparation } \\
\text { of financial reports by micro, small, and medium-sized enterprises } \\
\text { (MSMEs). Background Problems: The use of multi-platform online } \\
\text { transactions requires the validation and conversion of the data, which can } \\
\text { be an issue during the reconciliation process and the preparation of } \\
\text { financial reports. The issue of the data's integration is due to differences } \\
\text { in the interfaces used for the multi-platform transactions and the MSMEs } \\
\text { internal abilities. Novelty: The integration and treatment of online } \\
\text { transactions via multi-platforms should an internal records or database for } \\
\text { the MSMEs, the reconciliation process and preparing financial reports. } \\
\text { Research Methods: This research uses a quantitative method with partial } \\
\text { least squares structural equation modeling (PLS-SEM) analysis and } \\
\text { descriptive analysis to reveal the reconciliation process and the conditions } \\
\text { under which financial reports are prepared. Finding/Results: The } \\
\text { problems of integrating data from various platforms into internal reports } \\
\text { causes duplication of the internal reporting and a long reporting process } \\
\text { and the chance of errors. The digital receipt is treated as proof of a } \\
\text { manual transaction. Records' duplication is a technical issue that causes } \\
\text { delays in the processing time and reconciliation. None of the MSMEs } \\
\text { have a machine-to-machine based (automized) reconciliation process. } \\
\text { Conclusion: Transaction receipts from all the platforms affect the } \\
\text { transactions' recording, the reconciliation process, and the preparation of } \\
\text { financial reports. Digital receipts provide high levels of confidence } \\
\text { because of their completeness, accuracy, easiness, efficiency, simplicity, } \\
\text { and suitability for use by MSMEs. The adoption of online sales and } \\
\text { payments by MSMEs is highly effective, yet this has not been followed- } \\
\text { up with the data's integration into the reconciliation and accounting } \\
\text { process for preparing financial reports. }\end{array}$ & $\begin{array}{l}\text { Article information: } \\
\text { Received: September 23, } \\
\text { 2020. Received in revised } \\
\text { version: December 14, } \\
\text { 2020. Accepted: } \\
\text { December 18, } 2020 . \\
\text { Keywords: } \\
\text { automatization, digital } \\
\text { receipt, multiplatform } \\
\text { ecommerce, SMEs } \\
\text { accounting, reconciliation } \\
\text { and financial report } \\
\text { preparation }\end{array}$ \\
\hline
\end{tabular}

\footnotetext{
${ }^{1}$ Corresponding Author at Accounting, STIE Indonesia Membangun (Inaba), Jalan Soekarno-Hatta No. 448 Bandung 40266, Indonesia.

E-mail address: ferrykosadi@gmail.com(author\#1), wajibginting25@gmail.com (author\#2), vina.merliana@yahoo.com (author\#3)
} 


\section{INTRODUCTION}

\section{Research Background}

Sales and online payments are part of the digital ecosystem, which has developed and produced various services such as online commerce, ridesharing services, media distribution, and financial services. Those services are believed to significantly support Indonesia's economic development (Das et al., McKinsey, 2018:3).

In six Southeast Asian countries, the average contribution of the internet-based economy to their rapid economic development was 33\%. The highest development, an annual growth of $49 \%$, was experienced by Indonesia and Vietnam. Indonesia is even predicted to be an integral part of the global digital business supply chain, as its value in Indonesia could reach 130-150 billion USD in 2025 (Google \& Temasek \& Bain, 2019:18, Das et al., McKinsey, 2018:8).

The percentage of e-commerce used by new companies was $1.53 \%$ before $2010,28.06 \%$ from 2010 to $2016,45.3 \%$ from 2017 to 2018 , and 25.11\% in 2019 (BPS, 2019a:11). The highest economic development, with the internet's support, occurred in the last three years; especially during 2017 to 2018 when there was a surge in the number of e-commerce new users, indicating its significant adoption by enterprises.

Moreover, the transaction value of 17.21 trillion rupiah and transaction numbers of 24.82 million transactions (BPS, 2019a: 22) indicates that the interest in doing online transactions is high; thus, expanding the digital market as part of business transformation is imminent. Internet users in Indonesia are 171,260,000 out of a total population of $273,523,615$, which is $62.61 \%$ of internet users at the end of 2019 (Internetwordstats, 2020) can be used as a market opportunity to promote products from MSMEs. It means that e-commerce now provides a huge opportunity for micro, small and medium-sized enterprises (MSMEs) to market their products in digital markets. The number of enterprises in Indonesia in 2018 was 64,199,606 of which 64,194,057 were categorized as MSMEs (depkop.go.id, 2018). Despite the opportunity provided by e-commerce, only 4.7 million or $7.4 \%$ of the MSMEs used digital platforms to sell their products. In 2018, the number of MSMEs using e-commerce increased significantly to 9.61 million, or $15.13 \%$ increased (OJK, 2019), indicating that MSMEs started to become interested in using digital platforms.

A plethora of research investigated the use of e-commerce by MSMEs for marketing and the enterprises' readiness to utilize the technology. For example, some studies (for instance, see Astuti \& Nasution, 2014) found that the business owners' readiness to adopt the technology tended to be moderate and varied according to their gender, age, educational background, and income. They also suggested that the optimization of e-commerce for promotional purposes was still relatively low. Hariandi et al. (2019) found that MSMEs used e-commerce to compete and improve their performance. It can enhance a company's brand and corporate image, despite the entry barriers in terms of security and privacy (Jahanshahi and Zhang, 2013). MSMEs perceive the adoption of e-commerce as being beneficial, mostly due to its benefits for marketing and purchase activities, procurement, market expansion, increasing sales, external communications, company image, a speedy process, employees' productivity, and Indonesia's general advantage from adopting ecommerce compared to other developing countries (Rahayu \& Day, 2017). Historically, MSMEs in Indonesia did not belong to regional and global value chains due to low connectivity to the market, difficulties in accessing funding, and the lack of network knowledge. They also 
had a problem with their human resources, who were mostly incapable of handling a digital business. Fortunately, the government's proactive support with policies for the application of digital technology for businesses assisted the MSMEs to become a part of the digital supply chain (Capri, 2020).

Nevertheless, there are some obstacles that hinder the MSMEs' financial performance, which should have been integrated into their business performance, namely their difficulties in accessing funding, high borrowing costs, and consultants' lack of support (Wang, 2016). Banks' have been extremely cautious about granting loans to MSMEs, for instance, when evaluating the financial reports of MSMEs, it was clear to the banks that most of them were not ready or unable to prepare a standard financial statement, due to their lack of accounting knowledge, which has made accessing funding difficult for many of the MSMEs (Firdaus \& Wondabio, 2018). The managers', business owners', and human resources' qualities significantly determine the MSMEs' performance. Then, the government's role and support for improving the human resources in applying technology are also crucial to develop these businesses (Yanto et al., 2020).

The MSMEs' ability to produce financial reports still needs improvement. It can be seen from the data of the financial use report in 2017, which shows that of $7.52 \%$ of MSMEs have prepared financial reports and $6.55 \%$ have been incorporated (BPS, 2019b: 17). This number is relatively small compared to the significant transaction value and volume in Indonesia.

In general, the awareness and intention of MSMEs to adopt e-commerce for their business tends to increase the orientation of the businesses' integration with their marketing functions (Moqbel, 2014; Deshmukh, 2019).
The recording and reconciliation of internal transactions are integral parts of the process of preparing financial reports, as they determine the data's accuracy. The confirmation and completion of transactions based on data from various online sellers, payments, and shipping in ecommerce are generated in non-textual format such as image format or pdf format (paperless) automatically by the system. Manual processing is prone to errors, both in its internal rerecording and the transaction receipts' validation processes. An e-commerce digital receipt is generated by different provider systems, so that it has a different format and layout. In addition, there are also receipts for online transactions via social media, which tend to be manual.

The different user and provider interfaces affect the data's integration and reconciliation process (IFAC, 2002:3-4), which then needs calculation and settlement processes from various sources (Yezekyan, 2018); thus, a specific procedure to process the data before preparing any financial reports is required.

This research aims to investigate how MSMEs process digital data from the various ecommerce and social media resources into their internal transaction records, conduct the reconciliation processes, and prepare manual or computerized financial reports, so that the actual performance of the businesses can be shown in the financial reports.

This study also aims to analyze the MSME's internal financial recording process for online transactions and the effect this has on their reconciliation process and financial report preparation to conduct an accountancy data integration from ecommerce platforms, social media platforms and onsite or offline transactions, each of which has a different recording method that is commonly used by MSMEs. 
This research is expected to provide direction for supporting parties that aim to speed up the MSMEs' readiness to use technologybased accounting; thus, accounting and financial reporting issues can be minimized. Among other things is the possibility to use an application that can integrate the process, settlement, validation, and reconciliation of various online transaction platforms, and also speed up the process of accountancy's digitalization.

\section{LITERATURE REVIEW}

\section{E-commerce \& Transactions Record}

Online sales through business-to-customer (B2C) or business-to-business (B2B) processes have increased gradually (Laudon \& Traver, 2018:23-36). The increase is due to multi digital platforms that offers a different fundamental model of a connected network, treating businesses not as suppliers, distributors, or competitors, but as a network of partnerships prioritizing collaboration among the various stakeholders (Roger, 2016:64, 73-74). One of the promising collaborations is in the method of making payments, which has been transformed into a mobile device-based service (Tellez \& Zeadally, 2017:7).

An e-commerce platform with multi-providers has become a part of blockchain technology (Shorman et al., 2019) that provides openly distributed records and registers of transactions among connected parties. The transactions are verified in the form of a quickly reconciled ledger which is distributed to consumers (Christidis \& Devetsikiotis, 2016), which generates a digital receipt for its users. Deloitte (2018) stated that this process supports the migration from paper to digital processing.

Research into the use of financial transaction records in e-commerce with multiplatform providers indicates that users' interests and expectations are high. Users expect that ecommerce receipts will significantly impact financial performance (Nuryahya et al., 2019), help with decision-making, and increase profitability (Wulandari et al., 2020; Nurlinda et al., 2019). Similarly, companies designing webcommerce ideas independently also aim to create a seamless integration among their internal databases (Marhamah, 2016), making the recording process more efficient, and reducing the use of paper (Handayani, 2018).

Both e-commerce transactions in the marketplace and web-commerce tend to generate trust in the transaction data's accuracy and in the system's effectiveness in tracking e-transaction records (Singh, 2002). Overall, e-commerce features provide efficiency, improve performance, and increase the financial transaction records' accountability for the users. However, the different recording processes between offline and online data, both internally and externally, tend to create issues. The data storage system tends not to be in line with financial reports processing, creating incompatibilities that trouble the users (Charlesworth, 2018:307). As digital data usage keeps increasing, these storage and processing issues have become one of the main concerns for online businesses (Shakr \& Zomaya, 2019:314).

The tendency of MSMEs to use social commerce or social media for online transactions (Laudon \& Traver, 2018:432) creates difficulties for the data's integration, since social media platforms do not provide automatic transaction records. The issue also occurs when MSMEs use various marketplace platforms. The use of personalized web-commerce can be a solution, but the cost to build the web requires a great deal of investment, and expanding the MSMEs markets tends to be difficult. Hence, MSMEs prefer a marketplace that allows flexibility in the transactions and expansion with 
their exclusive features and affordable services. In other words, e-commerce is more beneficial for MSMEs. The issue that needs to be addressed is making the transaction records and reconciliation processes on social media and the marketplace reliable and useful for MSMEs. Those two online transaction platforms influence the internal recording process, the source of which is from the result of data on the online transactions conducted by the MSMEs.

MSMEs make up the highest percentage of enterprises in Indonesia. The majority of MSMEs mainly utilize the recordings made from social media and e-commerce as the platform to sell their products online. Social media does not provide automatic recording for a transaction; hence, MSMEs must have a manual and specific administrative recording for sales, payments, and shipping. In the e-commerce marketplace, financial administration is relatively more manageable as the platform provides digital transaction records. A business that uses social media and marketplace platforms tends to have difficulties integrating the receipts of its manual and digital transactions if they are not managed optimally. This mismanagement can affect the quality of the financial reporting of the companies.

Based on the elaboration above, the hypothesis related to the recording is that marketing, payment, and the delivery system for online transactions influence the MSMEs' transaction recording. This is proposed in the following subhypotheses:

Ha1 = Online sales have a positive effect on transaction records

$\mathrm{Ha} 2=$ Online sales have a positive effect on reconciliation

Ha3 = Payment has a positive effect on transaction records

Ha4 = Payment has a positive effect on reconciliation
Ha5 = Delivery has a positive effect on transaction records

Ha6 $=$ Delivery has a positive effect on reconciliation.

\section{Accounting and Reconciliation}

The function of accounting, as the manager of financial data (Laudon \& Laudon, 2018:48), includes reconciliation to compare the data obtained from various sources (Turner et al., 2017:88) and to confirm the settlement for every transaction (Nakajima, 2011:25; Hall. 2011:77; Oliveira, 2018).

The reconciliation process for three types of settlements, namely invoices, purchase orders, and shipping documents (Schultze, 2018) can be conducted by means of a paper, electronic, or mixed system (Deshmukh, 2006:152; Nakajima, 2011:117; Kay \& Ovlia, 2014:322), with accurate and balanced data as the output (Turner et al., 2017:230).

The improvement of the MSMEs' human resources in accounting, especially related to their management of digital receipts from ecommerce platforms, needs to be conducted to avoid data duplication (Rudiantoro \& Siregar, 2012; Anisah \& Pujiati, 2018; Putra, 2018). Abboora et al. (2016) also suggested that human resources' improvements can also support the data's validation to improve the quality of the reconciliation, which is vital to the financial reports' quality.

MSMEs tends to do their reconciliation separately by reprocessing transaction data from e-commerce platforms, then merging the data on the transactions from social media before preparing the financial reports (Deloitte, 2018). This process is not efficient and is prone to data duplication, due to potential human errors during the data's recording and merging from various platforms. The possibility of human error is high, as many MSMEs do not have human 
resources who understand the standard financial reporting preparation process. International reports indicate that the MSMEs' manual reconciliation process has an error rate of $41 \%$; it then takes 9 to 10 days to correct the errors (Deloitte, 2019). This tendency can also happen in Indonesia, where $7.52 \%$ of the financial reports come from MSMEs (BPS, 2019b: 17). An understanding of standard financial reports is needed to process a high number of financial reports. Hence, significant support for the intensification and access to digital technologybased recording systems is essential for improving the MSMEs' performance and marketability on digital platforms.

Some research into reconciliation investigated the accounting information system (AIS) product's application for companies' internal databases (Rahardja et al., 2018). The application tends to be effective for mid-level companies with relatively stable business conditions. The companies usually require the integration of transaction receipts from various e-commerce platforms and social media for validation, as well as conversion purposes (Hall, 2011:630). Other research demonstrated the wider application of information technology systems through a machine-to-machine based process. However, this process requires the MSMEs to integrate their internal information systems with the digital business supply chain. (Abboora et al., 2016; Ertz et al., 2016; Bakhtouchi, 2019; Charlesworth, 2018:307; Shakr \& Zomaya, 2019:314). This process enables online transactions with a digital receipt, reconciliation, and financial reporting preparations to be processed automatically by the system. Unfortunately, this system is only currently accessible by companies with significant financial resources and proper infrastructure.

If MSMEs can optimize and manage digital receipts properly, the reconciliation process will be effective and efficient (Brandon, 2006:311; Rosa \& Caserio, 2013). With regular reconciliation, proper digital receipt management can also increase data update speeds and accuracy (Mazza et al., 2016), eventually supporting an efficient financial reports' preparation process.

The conceptual framework (Figure 1) of this research comprises of three main processes: transaction matching, account reconciliation, and journal entries. Automatic or manual processes can conduct the last process after the data are received, processed and prepared for financial reporting.

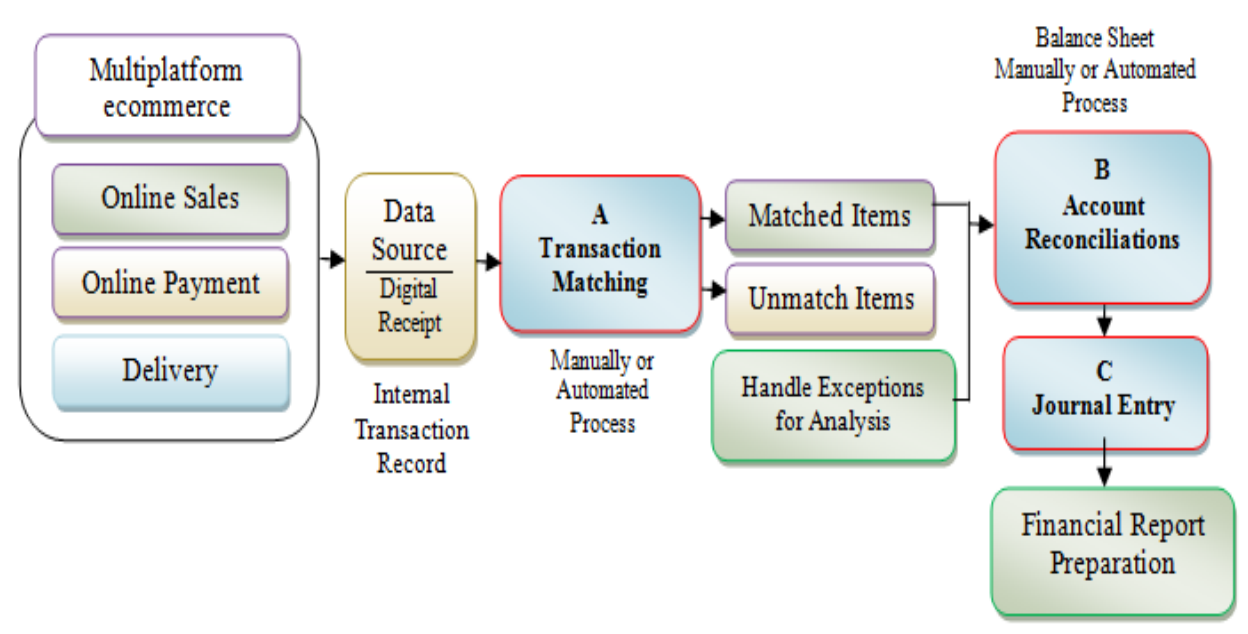

Figure 1. Conceptual Framework Source: Literature Review 
Based on the explanation above, the hypothesis related to the reconciliation and preparation for financial reporting in this research is as follows:

Transaction recording and reconciliation influence the arrangement of financial reports.

The whole hypothesis is explained by the following sub-hypotheses:

Ha1 = Online sales have a positive effect on transaction records

$\mathrm{Ha} 2=$ Online sales have a positive effect on reconciliation

Ha3 = Payment has a positive effect on transaction records

Ha4 = Payment has a positive effect on reconciliation

Ha5 = Delivery has a positive effect on transaction records

Ha6 $=$ Delivery has a positive effect on reconciliation

Ha7 $=$ Transaction records has a positive effect on reconciliation

Ha8 = Reconciliation has a positive effect on financial statement.

\section{METHOD, DATA, AND ANALYSIS}

\section{Research Method}

This research employed a quantitative method to reveal the variables' causal relationship (Cater \& Al hakim, 2009:12). Partial least squares structural equation modeling (PLS-SEM) was used to analyze the relationship between a theoretical causal model and the empirical data (Hair et al., 2011) with various constructs and indicators (Haenlein \& Kaplan, 2004). This method can be used to analyze abnormal data, small-sized samples, and formative indicators. It accommodates complex model structures and heterogeneous data such as marketing, management, and information systems (Hair et al., 2014). Descriptive analysis was conducted to reveal the conditions related to the reconciliation process and the financial reports' preparation.

\section{Research Design}

This research used latent variables with online sales, payment, and delivery as exogenous variables and financial statements as the endogenous variable. There are also some intervening variables in this research. Transactions recording and reconciliation are endogenous variables that connect the exogenous variables (online sales and payments) to the endogenous variable (financial statements). Figure 2 shows the analysis model which was developed using PLSSEM.

Figure 3 shows the analysis model developed by using PLS-SEM and its manifest variables or indicators.

Manifest variables or indicators are arranged by reflection to reflect each latent and intervening variable (Hair et al., 2014. Budhiasa, 2016:1-6). Indicators with semantic differential scales (Chalil \& Barus, 2014:16; Budhiasa, 2016:16) can respond to various dimensions, including evaluation, potential, activity (Widhiarso, 2009), and emotional conditions or personality dimensions (Brown, 2006:233-234). The population in this research consisted of MSMEs owners participating in formal training held by the government in 2019. The training was divided into two batches, with the number of participants in each batch being around 25 to 40. The participants were selected using a purposive sampling technique. There were 60 respondents selected based on the following criteria: 1) Aimed to export their products. 2) Had experience with online transactions. 3) Passed the coaching program administrative requirements, especially the legal aspect that includes the preparation of financial reports. 


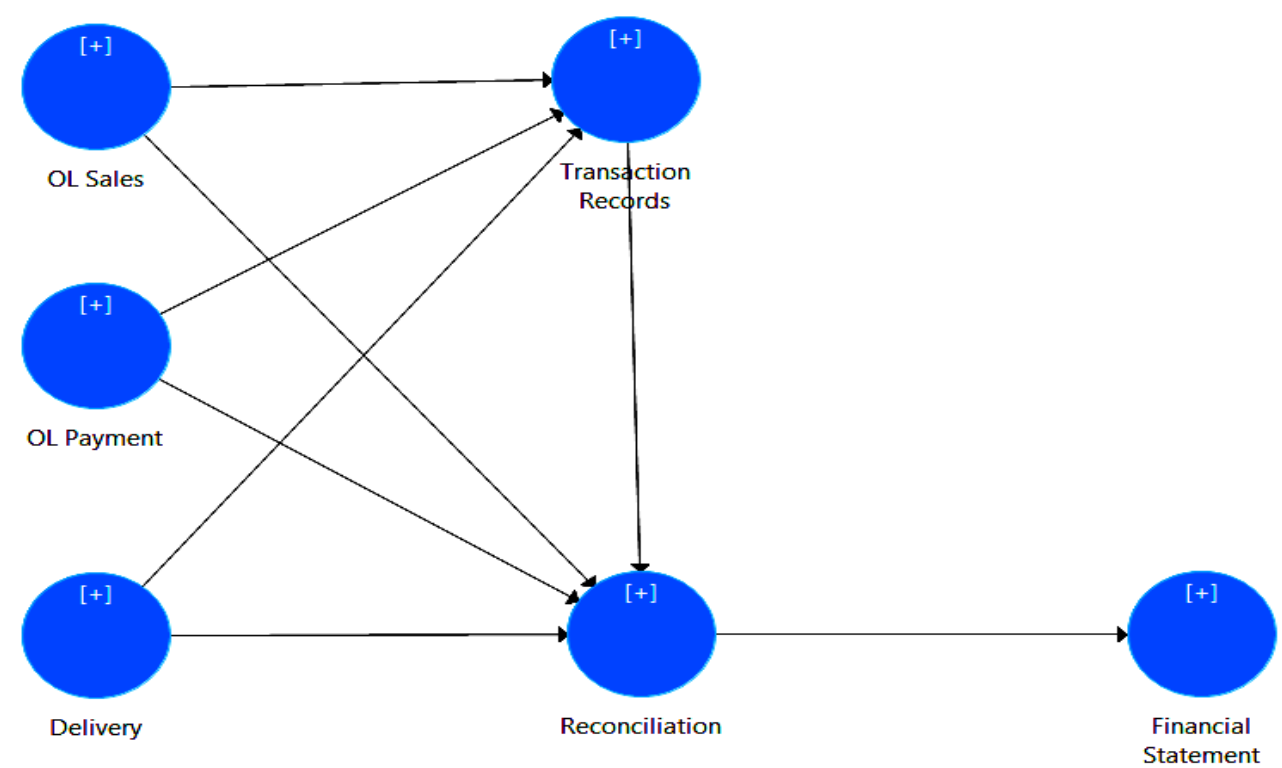

Figure 2. Analysis Model of Online Sales, Payment \& Delivery on Transaction Record \& Reconciliation for Financial Statement with PLS-SEM

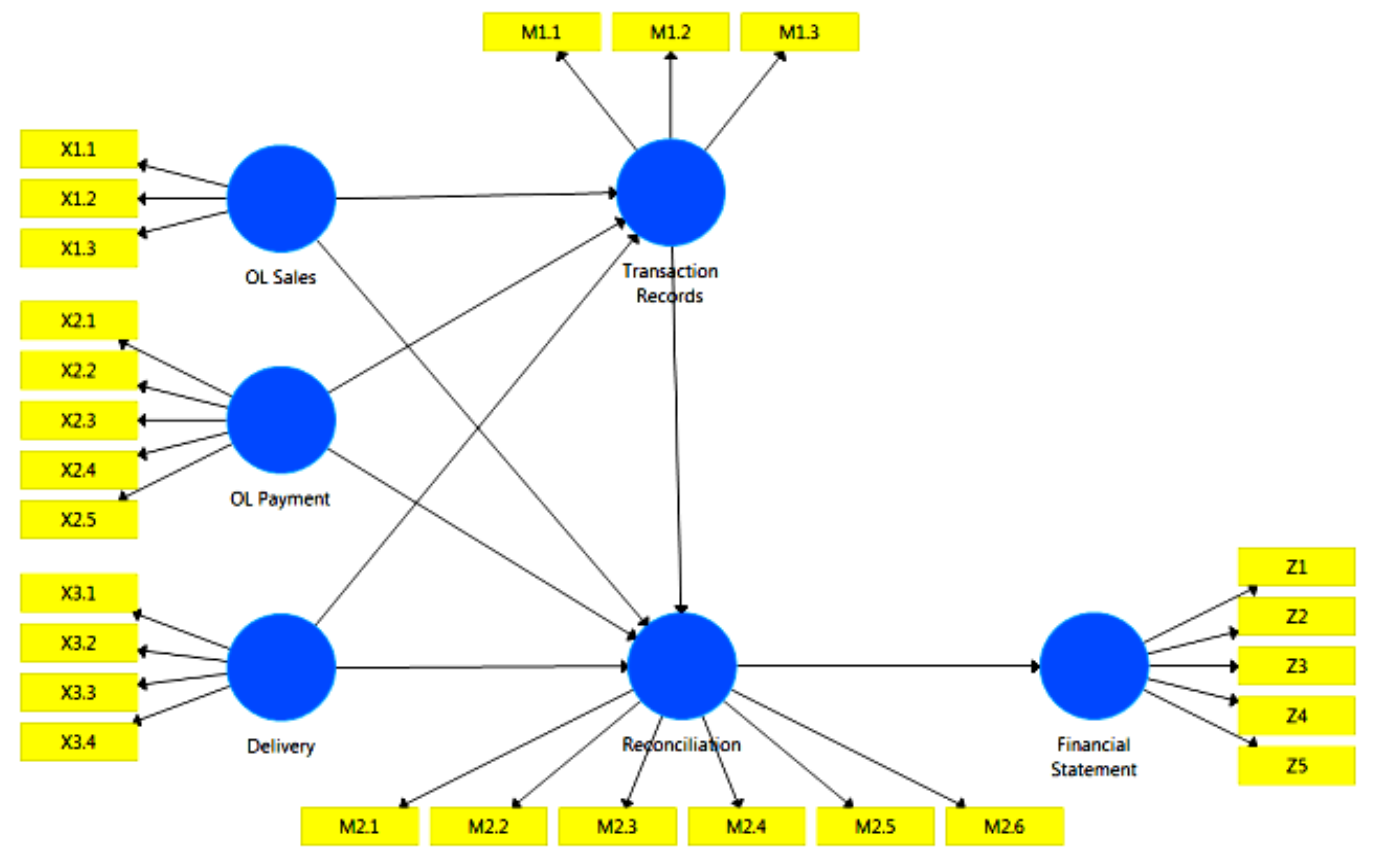

Figure 3. Analysis Model of Online Sales, Payment \& Delivery on Transaction Record \& Reconciliation for Financial Statement, PLS-SEM with manifest variable

Ten times the number of samples taken, the number of formative indicators or the most frequent line, were used to construct the inner model. There were three lines in the transaction record variable and four lines in the reconciliation variable. This number was not in line with the recommended number for reflection, which is 2 to 6 indicators (Hair et al., 2011). However, Sarstedt et al. (2016) suggested that the number of indicators can be unlimited.

The instrument of this research is a questionnaire which was developed based on a 
reflective indicator in each construct. The questionnaire was distributed to all 60 respondents. Then, an observation was conducted to confirm the reconciliation process and the accountability of the financial reports' preparation. The testing was performed after the data analysis model's specification had been determined through the measurement model with the outer model-algorithm. Furthermore, the structural model and hypothesis tests were conducted by using the inner model (Hair et al., 2014) through the bootstrapping technique or resampling method in SmartPLS Software version $3.3,2$.

\section{RESEARCH \& DISCUSSION}

\section{Result of Outer Model - Measurement Model}

Figure 4 shows the evaluation of each manifest variable or indicator using the outer model. The evaluation was conducted by observing the measurement result in loading factors and AVE to measure each construct's validity on its latent variable.

The findings demonstrated that the spread of the reflective indicator and the loading factor, after reducing to get near the covary, falls to around 0.8 and 0.9 respectively. The result indicates that all the indicators in all the variables are categorized as valid or in line with the convergence validity criteria of greater than 0.7. This result suggests that there is a positive relationship between each indicator and its variable. Table 1 shows that the average variance extracted (AVE) value is above 0.5, indicating that each indicator's convergence validity has met the criteria of PLS-SEM. The indicator also meets Cronbach's apha criteria by being greater than 0.60 with the spread of the composite reliability-CR value being more than 0.7 .

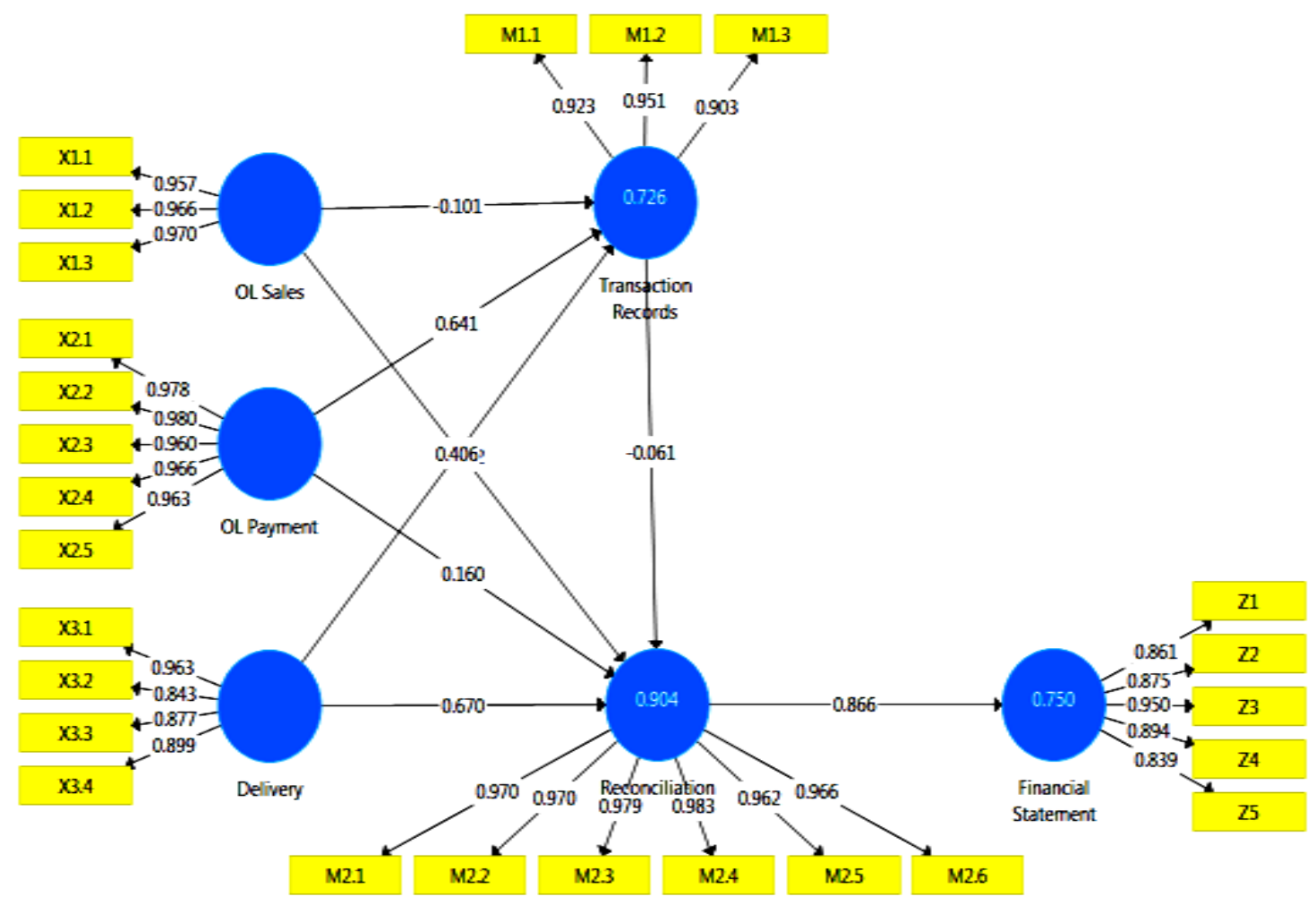

Figure 4. Result of Outer Model - Algorithms 
Table 1. Result of Reliability Test

\begin{tabular}{lcccc}
\hline & $\begin{array}{c}\text { Cronbach's } \\
\text { Alpha }\end{array}$ & Rho_A & $\begin{array}{c}\text { Composite } \\
\text { Reliability }\end{array}$ & Average Variance Extracted (AVE) \\
\hline OL Sales & 0.963 & 0.964 & 0.976 & 0.930 \\
OL Payment & 0.984 & 0.985 & 0.987 & 0.940 \\
Delivery & 0.918 & 0.925 & 0.942 & 0.804 \\
Transactions Record & 0.917 & 0.922 & 0.948 & 0.858 \\
Reconciliation & 0.988 & 0.988 & 0.990 & 0.944 \\
Financial Statement & 0.930 & 0.937 & 0.947 & 0.782 \\
\hline
\end{tabular}

Source: SmartPLS outer model-algorithm process results

The result of discriminant validity testing through cross loading or cross-correlation (Fornell-Lacker criterion) was conducted to compare the correlation between the construct's indicator and another construct. Table 2 shows that the indicators have met the criteria as they do not exceed the related construct's value and can be categorized as valid discriminants.

The discriminant validity measurement using the heterotrait-monotrait ratio (HTMT), as shown in Table 3, shows the fulfilment of the valid correlation criteria, which is less than 0.85 .

Overall, the result of the outer loading measurement with convergent validity and discriminant validity met the criteria in PLSSEM, indicating that each indicator's relationship with its variable was positive. Moreover, the interconnectedness among variables also showed a positive relationship, allowing the next stage of testing to be conducted.

Table 2. Result of Discriminant Validity Fornell-Lacker Criterion

\begin{tabular}{lcccccc}
\hline & Delivery & $\begin{array}{c}\text { Financial } \\
\text { Statement }\end{array}$ & $\begin{array}{c}\text { OL } \\
\text { Payment }\end{array}$ & $\begin{array}{c}\text { OL } \\
\text { Sales }\end{array}$ & Reconciliation & $\begin{array}{c}\text { Transactions } \\
\text { Record }\end{array}$ \\
\hline Delivery & 0.896 & & & & & \\
Financial Statement & 0.785 & 0.884 & & & & \\
OL Payment & 0.480 & 0.441 & 0.969 & & & \\
OL Sales & 0.732 & 0.687 & 0.379 & 0.965 & & \\
Reconciliation & 0.921 & 0.866 & 0.543 & 0.816 & 0.972 & \\
Transaction Records & 0.640 & 0.561 & 0.797 & 0.440 & 0.623 & 0.926 \\
\hline Source: SmartPLS outer model-algorithm process results & & & &
\end{tabular}

Table 3. Result of Discriminant Validity Heterotrait-Monotrait Ratio (HTMT)

\begin{tabular}{lcccccc}
\hline & Delivery & $\begin{array}{c}\text { Financial } \\
\text { Statement }\end{array}$ & $\begin{array}{c}\text { OL } \\
\text { Payment }\end{array}$ & $\begin{array}{c}\text { OL } \\
\text { Sales }\end{array}$ & Reconciliation & $\begin{array}{c}\text { Transactions } \\
\text { Record }\end{array}$ \\
\hline Delivery & & & & & & \\
Financial Statement & 0.841 & & & & & \\
OL Payment & 0.492 & 0.458 & & & & \\
OL Sales & 0.776 & 0.716 & 0.385 & & & \\
Reconciliation & 0.890 & 0.845 & 0.550 & 0.836 & & \\
Transactions Record & 0.687 & 0.602 & 0.838 & 0.463 & 0.651 &
\end{tabular}

Source: SmartPLS outer model-algorithm process results, with a note that there are results exceed 0.85 , namely the reconciliation with delivery of 0.89 which can still be tolerated because it is still below 0.9 for the reflective construct (smartpls.com) 


\section{Result of Inner Model - Structural Model}

Structural model testing using the inner model test with complete bootstrapping or the resample method was conducted to test the relationship between the construct and the hypothesis. The criteria applied were a $\mathrm{t}$ value $>1.65$ for the significance of 0.05 with $t>1.96$ for the significance of 0.1 and a p-value $<0.05$ with the value of path coefficient between -1 and 1 . If the value is close to -1 , then the significance is strong and negative, while if the value is close to 1 , the significance is strong and positive (Hair et al., 2014).

Figure 5 and Table 4 show the result of the inner model test with complete bootstrapping. The hypothesis testing indicated that online sales have a positive effect on transaction records (Ha1), payment has a positive effect on reconciliation (Ha4), and transaction records have a positive effect on reconciliation (Ha7). They are rejected as the value of $t$ was under 1.65 , and the p-value was above 0.05 . The sub- hypotheses accepted are as follows: 1) Online sales have a positive effect on reconciliation (Ha2). 2) Payment has a positive impact on transaction record (Ha3). 3) Transaction record has a positive impact on reconciliation (Ha5). 4) Delivery has a positive impact on reconciliation (Ha6). 5) Reconciliation has a positive effect on financial statement (Ha8). Those hypotheses are accepted as the value of $t$ was above 1.65 , and the $\mathrm{p}$-value was under 0.05 .

The significant negative correlations found were OL sales on transaction records, and transaction records on reconciliation. Whereas, the significant positive correlations found were: 1) Reconciliation on the financial statement with the value of 0.866 .2 ) Delivery on reconciliation with the value of 0.670 .3 ) OL payment on transaction records with the value of 0.641.4) Delivery on transaction records with the value of 0.406. 5) Sales on reconciliation with the value of 0.292. 6) OL payment on reconciliation with the value of 0.160 .

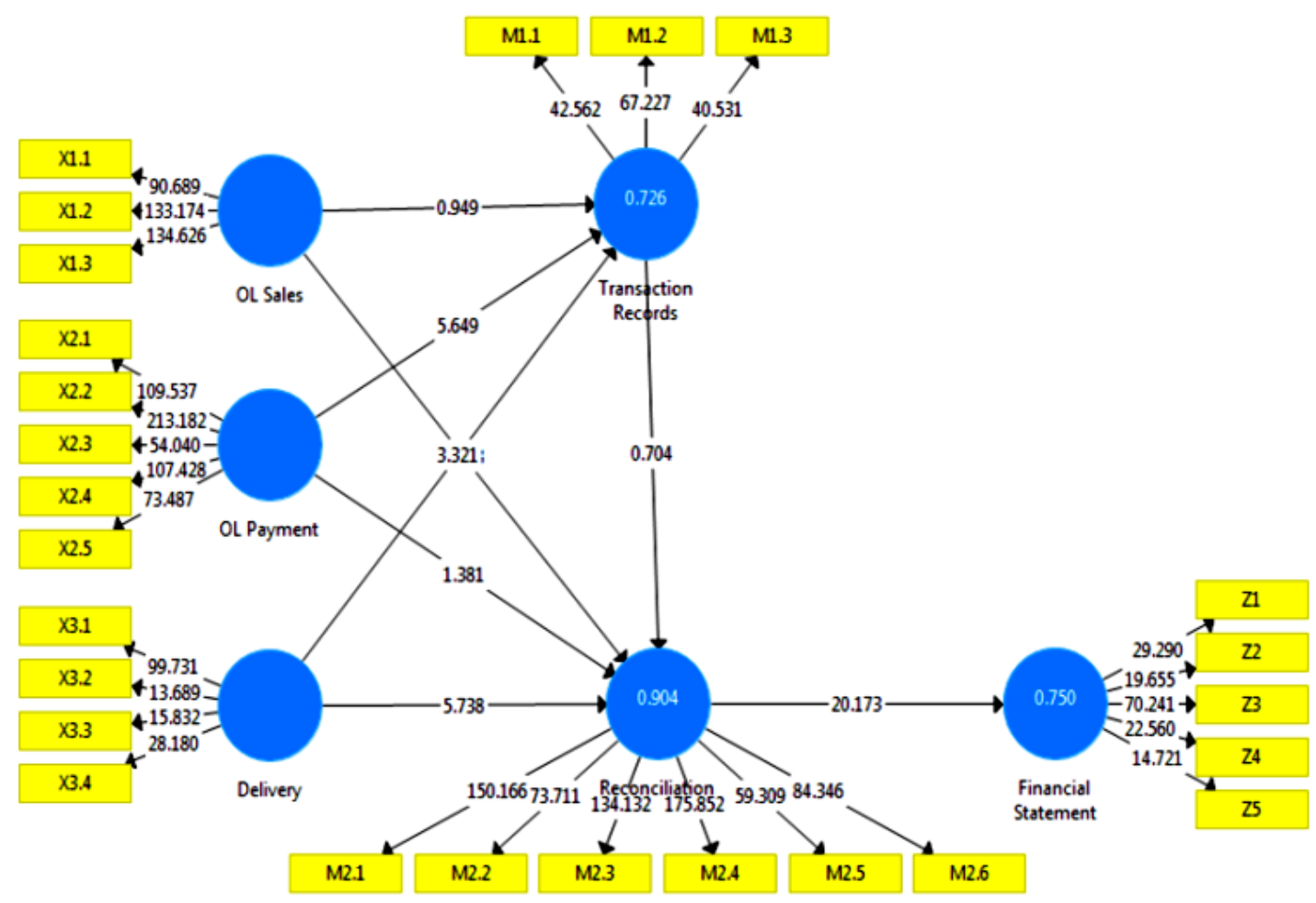

Figure 5. Result of Inner Model - Complete Bootstrapping 
Table 4. Result of Hypothetical Test - Inner Model

\begin{tabular}{lcccc}
\hline & Path Coefficient & T & P Values & Hypothesis \\
\hline OL Sales -> Transactions Record & -0.101 & 0.949 & 0.346 & Ha1 Rejected \\
OL Sales -> Reconciliation & 0.292 & 4.868 & 0.000 & Ha2 Accepted \\
OL Payment -> Transactions Record & 0.641 & 5.649 & 0.000 & Ha3 Accepted \\
OL Payment -> Reconciliation & 0.160 & 1.381 & 0.173 & Ha4 Rejected \\
Delivery -> Transactions Record & 0.406 & 3.321 & 0.002 & Ha5 Accepted \\
Delivery -> Reconciliation & 0.670 & 5.738 & 0.000 & Ha6 Accepted \\
Transactions Record -> Reconciliation & -0.061 & 0.704 & 0.484 & Ha7 Rejected \\
Reconciliation -> Financial Statement & 0.866 & 20.173 & 0.000 & Ha8 Accepted \\
\hline
\end{tabular}

Source: SmartPLS inner model complete bootstrapping result, modified.

Table 5. Result of Inner Model with R Square Determination

\begin{tabular}{lcc}
\hline & $\mathrm{R}^{2}$ (R Square) & Determination \\
\hline Financial Statement & 0.750 & Potential Determination \\
Reconciliation & 0.904 & Potential Determination \\
Transactions Record & 0.726 & Potential Determination \\
\hline Source: SmartPLS inner model complete bootstrapping result, modified.
\end{tabular}

The result of $\mathrm{R}$ square in Table 5 indicates that the determination of financial statements, reconciliation, and transaction records are categorized into the potential determination group or strong influence, based on the value criteria of the determination coefficient $\left(\mathrm{R}^{2}\right)$, which were 0.67 for potential, 0.33 for average, and 0.19 for weak (Chin, 1998).

The $\mathrm{f}^{2}$ test (f square) in Table 6 shows the various effects of the constructs. The effects are considered small if the value is 0.02 , medium if the value is 0.15 , and large if the value is 0.32 (Cohen, 1988). Sub-hypotheses are rejected if the size effect is small and accepted if the size effects are medium or large. The OL sales show the small size effects were found for records of transaction and reconciliation, which were 0.017 and 0.011 , respectively. The medium size effect was shown by delivery on transaction records, with a value of 0.251. Finally, the large size effects were shown by the reconciliation of the financial statements with a value of 3.002, delivery on reconciliation with a value of 1.553 , OL payments on transactions records with a value of 1.152 , OL sales reconciliation with a value of 0.404 , and $\mathrm{OL}$ payments on reconciliation with a value of 0.095 .

Table 6. Result of Inner Model with f Square

\begin{tabular}{lcc}
\hline & $\mathrm{f}^{2}$ & Effect \\
\hline OL Sales -> Transactions Record & 0.017 & Small Effect \\
OL Sales -> Reconciliation & 0.404 & Large Effect \\
OL Payment -> Transactions Record & 1.152 & Large Effect \\
OL Payment -> Reconciliation & 0.095 & Small Effect \\
Delivery -> Transactions Record & 0.251 & Medium Effect \\
Delivery -> Reconciliation & 1.553 & Large Effect \\
Transactions Record ->Reconciliation & 0.011 & Small Effect \\
Reconciliation -> Financial Statement & 3.002 & Large Effect \\
\hline
\end{tabular}

Source: SmartPLS inner model complete bootstrapping result, modified. 


\section{Result of Scoring Response}

In the processing of the data, the respondents' answers were scored by classifying their answers using the semantic differentiation scale. The responses on the scale were then further categorized into positive (6 and 7), moderate (4 and 5), and negative (1 and 2). The scoring results are shown in tables 6,7 , and 8 .

Table 6. Digital Receipt of Transactions Record Completeness \& Accuracy

\begin{tabular}{lccc}
\hline \multicolumn{3}{c}{$\begin{array}{c}\text { Transactions Record } \\
\text { Completeness \& Accuracy }\end{array}$} \\
\hline & OL Sales & OL Payment & Delivery \\
\hline Positive & $55.0 \%$ & $65.0 \%$ & $60.0 \%$ \\
Moderate & $35.0 \%$ & $35.0 \%$ & $30.0 \%$ \\
Negative & $10.0 \%$ & $0.0 \%$ & $10.0 \%$ \\
\hline
\end{tabular}

Source: Data Processing.

Table 6 shows that the respondents' confidence in a digital receipt, in terms of its completeness and accuracy, was high. The percentage of respondents with positive and moderate attitudes for online sales, payment, and delivery, when combined, was at least $90 \%$.

The high level of confidence in digital receipts (shown in Table 6) had a positive effect on the reconciliation process shown in Table 7. The combination of positive and moderate responses was at least $80 \%$ for all aspects. The result indicates that digital receipts have a positive effect on the reconciliation process. Although the recording and reconciliation were conducted manually, the availability of digital receipts made a positive contribution to the process and encouraged high positive responses, especially for the accuracy and suitability of the data (Turner et al., 2017: 230; Mazza et al., 2016) as well as in terms of efficiency (Deloitte, 2018; Rosa F.L. \& Caserio C., 2013; Brandon, 2006:311) and easiness. Although the control process was manual (Kay \& Ovlia, 2014:317; Hall, 2011:174; Schultze, 2018), the validation and conversion (Hall, 2011:630) were conducted separately (Hall, 2011: 506).

Table 8 shows that knowledge of the SAK standardization guide, based on the responses, was $45 \%$ positive and $25 \%$ moderate. The negative responses about the complexity of accounting and usage of accounting were $45 \%$ and $40 \%$, respectively.

Table 7. Reconciliation Processing

\begin{tabular}{lcccccc}
\hline \multicolumn{7}{c}{ Reconciliation } \\
\hline Positive & Easiness & Accuracy & Completeness & Simplicity & Efficiency & Suitability \\
Moderate & $55.0 \%$ & $75.0 \%$ & $60.0 \%$ & $65.0 \%$ & $55.0 \%$ & $55.0 \%$ \\
Negative & $25.0 \%$ & $5.0 \%$ & $20.0 \%$ & $20.0 \%$ & $30.0 \%$ & $30.0 \%$ \\
\hline
\end{tabular}

Source: Data Processing.

Table 8. Financial Statement Preparation Processing

\begin{tabular}{lccccc}
\hline & \multicolumn{5}{c}{ Financial Statement } \\
\hline & $\begin{array}{c}\text { Knowledge of SAK } \\
\text { Standardization } \\
\text { Guidance }\end{array}$ & $\begin{array}{c}\text { Complexity of } \\
\text { Accounting }\end{array}$ & $\begin{array}{c}\text { Usage of } \\
\text { Accounting }\end{array}$ & $\begin{array}{c}\text { Willingness to } \\
\text { Develop } \\
\text { Accounting }\end{array}$ & $\begin{array}{c}\text { The benefit of } \\
\text { Accounting } \\
\text { method }\end{array}$ \\
\hline Positive & $45.0 \%$ & $35.0 \%$ & $25.0 \%$ & $30.0 \%$ & $15.0 \%$ \\
Moderate & $25.0 \%$ & $20.0 \%$ & $35.0 \%$ & $20.0 \%$ & $40.0 \%$ \\
Negative & $30.0 \%$ & $45.0 \%$ & $40.0 \%$ & $50.0 \%$ & $45.0 \%$ \\
\hline
\end{tabular}

Source: Data Processing. 


\section{Analysis and Discussion}

Based on the data's processing, and observations we made, some potential MSMEs in terms of total asset ownership value, number of employees, total sales turnover and have successfully exported, although not yet sustainable in exporting. suggest that the influence of online selling on transactions record with negative value of -0.101 and transactions record on reconciliation with negative value of -0.061 (table 4) indicated that there were a few problems in integrating the online transaction data from the various platforms used by the MSMEs for their internal recording and reconciliation process. While the better values online payment on transactions record and reconciliation (table 4) are caused by the bank confirmation and the more attention paid by the MSMEs on the profit they made. So is are the delivery values on transactions record and reconciliation system which are more sensitive on their customer's trust.

The potential determination and effect of each construction and the result of the reconciliation process showed that the MSMEs have realized the relationship between receipt, recording, reconciliation, and financial reporting, and the importance of those processes. However, the low score for the effect of transaction recording toward reconciliation indicated that there was an obstacle in the reconciliation process. In addition, the problems with accounting and preparing the financial report were indicated by the low score for the consistency of financial reporting, the willingness to comprehend more about accountancy and an awareness of the advantages of formally arranging the financial report. The contradiction also occurred between the good result for reconciliation and the poor result for arranging the financial report. This gap suggested some obstacles between the reconciliation process and the arrangement of the financial report. The reconciliation process, with a relatively high score, showed a great deal of attention and awareness by the MSMEs to online transaction data, but their awareness of arranging a formal financial report was poor.

The observation revealed that the transaction recording process, reconciliation, and preparation of the financial report were conducted separately and manually. The process used a spreadsheet application which was not integrated with financial reporting. This process was prone to creating duplicate records of transaction receipts from both e-commerce and social media. This finding is similar to Deloitte (2018; 2019) and Abboora et al. (2016), who found the same problems with the separate and manual recording processes. Raharja et al. (2018) also found that even the website personally built by the MSMEs was prone to duplicating financial data during the reconciliation process. For market expansion purposes, the recording process used an application from other providers but this could not integrate the transaction data automatically.

In terms of e-commerce's paperless trend (Deloitte, 2018; Handayani, 2018), especially for generating invoices, payment receipts, and shipping receipts, the MSMEs in this research had adopted the trend effectively. Also, positive responses were found in terms of the receipts' efficiency and accuracy (Christidis \& Devetsikiotis, 2016; Deloitte, 2018) as well as the tracking of transaction receipts (Singh, 2002). The confidence level of MSMEs in the accuracy and completeness of digital receipts was also high, as the reconciliation process during the data's integration from various platforms was effective (Charlesworth, 2018: 307; Shakr \& Zomaya, 2019:314). However, MSMEs still manually confirmed the sales data from their invoices, and payment data from the financial providers and banks. The transaction 
records' duplication rate was high during the validation and conversion process before the reconciliation, which was a conceptual process (Hall, 2011:630), for each of the platforms used.

The human resources' capabilities for data processing using IT and accounting seemed to be poor (Yezekyan, 2018; Firdaus\& Wondabio, 2018; Yanto et al., 2020), as the processes were conducted separately and manually. This was in line with the responses to questions related to accounting's complexity, which showed a negative trend of $45 \%$. The inconsistency of the accounting in the MSMEs' business activities was relatively high, with only $25 \%$ of respondents consistently undertaking the accounting and financial reports' preparation. Most of the respondents $(40 \%)$ said that they tried to organize their accounts and financial reports only when necessary, such as when accessing financial data for their banks.

Nevertheless, MSMEs that have used the features of IT in the marketplace, such as using a payment method or registering as partners, suggest positive responses. This finding is in line with the concepts and previous research reported by experts (see, for example, Roger, 2016:64, 73-74; Shorman et al., 2019). In general, all the respondents have experienced the benefits of the marketplace's features. However, their willingness to develop their accounting knowledge is small, as the negative responses on this issue were $50 \%$. The urgency to prepare financial reports and accounting based on the standards was also low. Only $15 \%$ of respondents give positive responses on the importance of financial reporting and accountability for the improvement of their businesses' performance.

A digital record is processed as a manual receipt since it is re-recorded internally by a company. The matching process is conducted by comparing the payment transaction data with the financial institution's cash entry records. In terms of the relationship effects, these conditions signify that the effects of OL sales on transaction records, OL payments on reconciliation, and transaction records on reconciliation are rejected as the effects' size was small.

The observation found that the issues with adopting integrated AIS, in line with several experts (Deshmukh, 2006:186; Mukherjee \& Roy. 2017:4; Xia, 2016; Willems, 2018), were related to the lack of resources, costs, and infrastructure. The migration process from paper to digital processing, for instance, takes time because it requires MSMEs to strengthen their technology and network culture (Xia. 2016; Willems, 2018). The use of social receipts in the internal transaction recording process, reconciliation, and financial reports' preparation can begin with manual processing to train the human resources, but needs to move to automatization (Deloitte, 2018). The issues of integrating the AIS's adaptation need to be addressed by the MSMEs.

Finally, a contribution was required, in terms of an application, to bridge the data's integration process, transaction recording, and the reconciliation of various multi-platform providers including those which were able to capture social media transactions. This integration was expected to ease the next step, namely the financial reporting of the MSMEs.

\section{CONCLUSION, LIMITATION, AND SUGGESTION}

\section{Conclusion}

Digital receipts from e-commerce platforms and non-digital receipts from other platforms affect the transaction records, reconciliation, and financial reports' preparation. There were some obstacles to the integration process, reconciliation, and financial reports' preparation that came from various platforms which had 
undertaken the transactions conducted by the MSMEs.

The respondents have a high level of confidence in digital receipts, in terms of their completeness, accuracy, easiness, simplicity, and suitability for transaction records, reconciliation, and the preparation of financial reports by the MSMEs. However, in terms of multi-platform integration, there are technical issues in the data's validation and conversion process, primarily related to the receipts from social media platforms. This technical issue is due to the manual processing and duplication during the transactions' recording.

The transaction recording process, reconciliation, and financial reports' preparation using automatization have not been conducted effectively by the MSMEs. However, the trend is positive, and the learning process for the transactions' automatization on various platforms signifies that the MSMEs are moving toward the digitalization process. The human resources for the system's adoption, especially for sales and online payments, are promising, but they have not processed the reconciliation, accounting, and financial reports' preparation effectively. This created a gap between technologies' utilization for business, marketing with accountancy, and financial reporting.

\section{Limitation and Suggestion}

Some of the limitations of this research are the lack of coverage of the respondents who have used automatization to process the reconciliation and the financial report's preparation; thus, issues on the automatization process, including cloud accounting, cloud storage, and data distribution from networking e-commerce platforms were not portrayed, neither were the limitations of the social media's transaction evaluations in detail.
The challenges and opportunities include a gap in the mediation between AIS's automatization facility providers and the MSMEs. Further research needs to expand the scope and speed of the adaptation, as well as the adoption process for a digital processing system to optimize and improve the potential of the MSMEs.

\section{ACKNOWLEDGEMENT}

We want to extend our gratitude to the Ministry of Research, Technology, and Higher Education, which awarded us a Novice Lecturer Research Grant in 2020. We would also thank the Foreign Trade Sector of the Department of Trade and Industry of West Java for permission to access the respondents.

\section{REFERENCE}

Abboura, A., Sahri, S., Baba-Hamed, L., Ouziri, M., \& Benbernou, S. (2016). Quality-based online data reconciliation. ACM Transactions on Internet Technology (TOIT), 16(1), 1-21.

Anisah, N., \& Pujiati, L. (2018). Kesiapan Usaha Mikro Kecil dan Menengah Dalam Penerapan Standar Akuntansi Keuangan Entitas Mikro Kecil dan Menengah Untuk Menunjang Kinerja. JAD: Jurnal Riset Akuntansi dan Keuangan Dewantara, 1(1), 45-56. DOI: 10.26533/jad.v1i2.239

Astuti, N. C., \& Nasution, R. A. (2014). Technology readiness and e-commerce adoption among entrepreneurs of SMEs in Bandung city, Indonesia. Gadjah Mada International Journal of Business, 16(1), 69-88.

Bakhtouchi, A. (2019). Data reconciliation and fusion methods: A survey. Applied Computing and Informatics. https://doi.org/10.1016/j. aci.2019.07.001

BPS, Badan Pusat Statistik Indonesia. (2019a). Statistik E-Commerce 2019, /BPS Catalog: 8101004, ISBN: 978-602-438-290-2. 
BPS, Badan Pusat Statistik Indonesia. (2019b). Analisis Hasil Sensus Ekonomi 2016 lanjutan, Potensi Peningkatan Kinerja Usaha Mikro Kecil.

Budhiasa, S. (2016). Analisis Statistik Multivariate dengan Aplikasi SEM PLS SmartPLS 3.2.6, Pengembangan Model Struktural, Hierarchies Latent Second Order Model, Mediasi Ganda. Udayana University Press.

Brown, T. A. (2006). Confirmatory factor analysis for applied research. The Guilford Press. New York.

Capri, A. (2020). Micro and small business in Indonesia's digital economy keys to developing new skills and human capital. Asia Pacific Foundation of Canada. https://apfcanada-MSMEs.ca/

Cater, A S. \& Al Hakim, L. (2009). Information system research methods, epistemology, and applications. Information Science Reference, IGI Global, USA.

Chalil, D., \& Barus, R. (2014). Analisis Data Kualitatif: Teori dan Aplikasi dalam Analisis SWOT, Model Logit, dan Structural Equation Modeling (Dilengkapi dengan Manual SPSS dan Amos).

Charlesworth, A. (2018). Digital marketing, a practical approach. $3^{\text {rd }}$ Edition. Routledge. Taylor \& Francis Group. London \& New York.

Chin, W. W. (1998). Issues and opinion on structural equation modeling. MIS Quarterly, 22(1), VII-XVI

Christidis, K., \& Devetsikiotis, M. (2016). Blockchains and smart contracts for the internet of things. Ieee Access, 4, 22922303.

Cohen, J. (1988). Statistical power analysis for the behavioral sciences. Lawrence Erlbaum Associates. Hillsdale, New Jersey.

Das, K. Tamhane, T. Vatterott, B. Wibowo, P. \&Wintels, S. (2018). The digital archipelago: how online commerce is driving Indonesia's economic development. McKinsey. Executive summary, Retrieved from

https://www.mckinsey.com/ /media/McKin sey/Featured\%20Insights/Asia\%20Pacific/T he $\% 20$ digital $\% 20$ archipelago $\% 20 \mathrm{How} \% 20$ online $\% 20$ commerce $\% 20$ is $\% 20$ driving $\% 20$ I ndonesias\%20economic\%20development/T he-digital-archipelago-Executivesummary.ashx

Deloitte. (2018). SME digital payments, new opportunities to optimize, the paytech revolution series. Retrieved from https://www2.deloitte.com/content/dam/Del oitte/au/Documents/financialservices/deloitte-au-fs-sme-digitalpayments-270218.pdf

Deloitte. (2019). Process automation in financial closing and reporting, The CFO Program, Deloitte China.

Depkop.go.id. (2018). http://www.depkop.go.id/data-umkm

Deshmukh, A. (2006). Digital accounting the effect of internet and ERP on accounting. IRM Press. Idea Group Inc. USA.

Deshmukh, S. U. (2020). Impact of E-Business on Business Association. International Journal of Engineering and Management Research, 9. www.ijemr.net. https://doi.org/10.31033/ijemr.9.6.2.

Ertz, M., Durif, F., \& Arcand, M. (2016). Collaborative consumption: Conceptual snapshot at a buzzword. Journal of Entrepreneurship Education, 19(2), 1-23. Pages Posted: 26 Jun 2016 Last revised: 14 Dec 2016.

https://papers.ssrn.com/sol3/papers.cfm?abs tract_id=2799884

Firdaus, R., \& Wondabio, L. S. (2017, August). Financial Report for Micro, Small, and Medium Enterprise According to Financial Accounting Standards: Case Study Rafita Cake. In 6th International Accounting Conference (IAC 2017). Atlantis Press.

Ghozali, I. (2014). Structural Equation Modeling Metode Alternatif dengan Partial Least Square (PLS) Dilengkapi Software SmartPLS 3.00 Xistat 2014 dan WarpPLS 
4.0. Edisi ke-4. Semarang: Badan Penerbit Universitas Diponegoro Semarang.

Google \& Temasek \& Bain \& Company. (2019). E-Conomy SEA 2019, Swipe Out and to the Right: South East Asia's $\$ 100$ Billion Internet Economy.

Haenlein, M., \& Kaplan, A. M. (2004). A beginner's guide to partial least squares analysis. Understanding statistics, 3(4), 283-297.

DOI: 10.1207/s15328031us0304_4

https://www.researchgate.net/publication/22 8861711_A_Beginner's_Guide_to_Partial_L east_Squares_Analysis/link/5a2cee61a6fdcc fbbf876397/download

Hair, J. F., Sarstedt, M., Ringle, C. M., \& Mena, J. A. (2012). An assessment of the use of partial least squares structural equation modeling in marketing research. Journal of the academy of marketing science, 40(3), 414-433.

Hair Jr, J. F., Sarstedt, M., Hopkins, L., \& Kuppelwieser, V. G. (2014). Partial least squares structural equation modeling (PLSSEM). European business review.

Hall. J. A. (2011). Accounting information systems. $7^{\text {th }}$ Edition. Cengage Learning. The USA.

Handayani, S. (2018). Perancangan sistem informasi penjualan berbasis e-commerce studi kasus toko kun jakarta. ILKOM Jurnal Ilmiah, 10(2), 182-189.

MS Irwan Hariandi, I. (2019). E-Commerce, Competitive Advantage And Business Performance Of Banyuwangi Small And Medium-Sized

Enterprises. INTERNATIONAL JOURNAL OF SCIENTIFIC \& TECHNOLOGY RESEARCH, 8(8).

IFAC-Information Technology Committee of International Federation of Accountants. (2002). E-Business and The Accountant, February 2002, Retrieved from http://www.ifac.org

Internetworldstats. (2020). Internet usage in Asia. https://www.internetworldstats.com/stats3.h tm

Jahanshahi, A. A. \& Zhang, S. X. (2013). ECommerce for SMEs: empirical insights from three countries. Journal of Small Business and Enterprise Development Vol. 20 No. 4, 2013 pp. 849-865, Emerald Group Publishing Limited. 1462-6004, DOI 10.1108/JSBED-03-2012-0039

Kay, D. \& Ovlia, A. (2014). Accounting information systems, The Crossroads of Accounting \& IT. $2^{\text {nd }}$ Edition. The USA. Pearson Education Inc.

Laudon, K. C. \& Laudon, J. P. (2018). Management information system, managing the digital firms. $15^{\text {th }}$ Edition, Global Edition. Pearson Education Inc. New York.

Laudon, K, C. \& Traver, C. G. (2018). Ecommerce business, technology, society. $13^{\text {th }}$ Edition. Pearsons Education Inc. USA.

Marhamah, M., Hidayatuloh, S., \& Irawan, A. (2016). Sistem e-commerce B2C pada PT. Harapan Sentosa Nusantara Jakarta Pusat. Studia Informatika: Jurnal Sistem Informasi, 9(2).

Mazza, T., Azzali, S., \& Brooks, L. (2016). Determinants of Information Technology Audit Quality. In Strengthening Information and Control Systems (pp. 237-258). Springer, Cham.

Mancini, D., Dameri, R. P., \& Bonollo, E. (2016). Strengthening information and control systems. Springer International Publishing.

Moqbel, M. A. (2014). The impact of accounting information systems (AIS) On e-commerce analytical study-service sector. Jordan ASE. International Journal of Scientific and Technology Research, 3(1).

Mukherjee, M., \& Roy, S. (2017). E-commece and Online Payment in The Modern Era. International Journal of Advanced Research in Computer Science and Software Engineering, 7(5). Available online at www.ijarcsse.com. DOI 10.23956/ijarcsse/SV7I5/0250 
Nakajima, M. (2011). Payment system technologies and functions: innovations and developments. IGI Global.

Nurlinda. Fathimah, V. (2019). Determinan adopsi e-commerce dan dampaknya pada kinerja usaha mikro kecil menengah (UMKM). Jurnal Riset kuntansi dan Keuangan, 7 (3), 2019, 445-464.

Nuryahya, E. Ichsana, Y. Andini, K. M. (2019). Perilaku pengguna sistem informasi akuntansi di e-commerce. Jurnal Akuntansi Multparadigma, v.10(3), p. 502-515

OJK-Otoritas Jasa Keuangan. (2019). The impact of e-commerce adoption on MSMES performance and financial inclusion (fi) in Indonesia

Oliveira, J. (2018). Accountants roles and accounting related technologies. Quinn, M. \& Strauss, E. (Eds). The Routledge Companion to Accounting Information Systems. Routledge, Taylor Francis Group. London \& New York.

Putra, Y. M. (2018). Pemetaan penerapan standar akuntansi keuangan EMKM. Profita: Komunikas Ilmiah Akuntansi dan Perpajakan v.11(2) p-ISSN: 2086-7662, eISSN: 2622-1950

Rahardja, U. Aini, Q. Azizah, N. Santoso, N. P. L. (2018). Online Accounting Effectiveness in Supporting the Reconciliation Process. NJCA - Volume 3, Nomor 2, Desember 2018: $105-112$.

Rahayu, R. \& Day J.(2017). E-commerce adoption by SMEs in developing countries: evidence from Indonesia. Eurasian Bus Rev 7:25-41, DOI 10.1007/s40821-016-0044-6

Rogers, D. L. (2016). The digital transformation playbook: Rethink your business for the digital age. Columbia University Press.

La Rosa, F., \& Caserio, C. (2013). Are auditors interested in XBRL? A qualitative survey of big auditing firms in Italy. In Accounting information systems for decision making (pp. 13-45). Springer, Berlin, Heidelberg.
Rudiantoro, R., \& Siregar, S. V. (2012). Kualitas laporan keuangan umkm serta prospek implementasi SAK ETAP. Jurnal Akuntansi dan Keuangan Indonesia, 9(1), 1-21. DOI: http://dx.doi.org/10.21002/jaki.2012.01

Schultze, U. (2018). Leveraging accounting information systems for standardization, a case study of a SOX compliance journey. Quinn, M. \& Strauss, E. (Eds). The Routledge Companion to Accounting Information Systems. Routledge, Taylor Francis Group. London \& New York.

Shakr, S. \& Zomaya, A.Y. (Eds). 2019. Encyclopedia of big data technologies. Springer Nature Switzerland AG.

Shorman, S. M., Allaymounq, M., \& Hamid, O. (2019). Developing the E-commerce model a consumer to consumer using blockchain network technique. International Journal of Managing Information Technology (IJMIT) Vol, 11 .

Singh, M. (2002). E-services and their role in B2C e-commerce. Journal of Service Theory and Practice, DOI: 10.1108/09604520210451911

Smartpls.com. (2015). Discriminant validity assessment,

https://www.smartpls.com/documentation/al gorithms-and-techniques/discriminant-

validity-

assessment\#: :text=Discriminant\%20Validi ty\%20Assessment\%20in\%20SmartPLS\&tex $\mathrm{t}=$ cross $\% 2$ Dloadings $\% 2 \mathrm{C} \% 20$ and,establishe d\%20between\%20two\%20reflective\%20con structs.

Téllez, J., \& Zeadally, S. (2017). Security in mobile payment systems. In Mobile Payment Systems (pp. 93-106). Springer, Cham.

Turner, L. \& Weickgenannt, A. \& Copeland, M. K. (2017). Accounting information system, controls, and processes. $3^{\text {rd }}$ Edition. John Willey \& Sons Inc. USA

Wang, Y. (2016). What are the biggest obstacles to growth of SMEs in developing countries?-An empirical evidence from an 
enterprise survey. Borsa Istanbul Review, 16(3), 167-176.

http://www.elsevier.com/journals/borsaistanbul-review/2214-8450

Widhiarso, W. (2009). Semantik diferensial. Fakultas Psikologi UGM. Retrieved from http://widhiarso.staff.ugm.ac.id/files/3__semantik_diferensial.pdf

Willems, V. (2018). European federation of accountants and auditors for SMEs-EFAA International Conference 2018, Digital Transformation of SMEs. July 2018

Wulandari. Maslichah. Sudaryanti, D. (2020). Pengaruh ecommerce dan penggunaan sistem informasi akuntansi pada pengambilan keputusan dalam berwirausaha. E-JRA Vol. 09 No. 04.
Xia, Q. (2016). Study on impact of electronic commerce on the development of financial accounting. $4^{\text {th }}$ International Education, Economics, Social Science, Arts, Sports, and Management Engineering Conference (IEESASM, 2016).

Yanto, H. K. Pramono S. E. \& Jati K. W. (2020). Utilizing accounting information for enhancing performance of Indonesian SMEs. Academy of Accounting and Financial Studies Journal Volume 24, Issue 2.

Yezekyan, L. (2018). Compilation of ecommerce data for balance of payments statistics. IFC-Irving Fisher Committee on Central Bank of Armenia Workshop of External Sector Statistics. Central Bank of Armenia. Dilijan, Armenia, 11-12 June 2018 